\title{
Bonding SiCp/Al Composites via Laser-Induced Exothermic Reactions
}

\author{
Yifeng Wang, Guangjie Feng *, Yan Wei, Bingxu Hu and Dean Deng \\ College of Materials Science and Engineering, Chongqing University, No. 174, Shazhengjie, \\ Chongqing 400044, China; wangyf0902@cqu.edu.cn (Y.W.); 201909131163@cqu.edu.cn (Y.W.); \\ 202009021009@cqu.edu.cn (B.H.); deandeng@cqu.edu.cn (D.D.) \\ * Correspondence: fenggj@cqu.edu.cn
}

Citation: Wang, Y.; Feng, G.; Wei, Y.; $\mathrm{Hu}$, B.; Deng, D. Bonding SiCp/Al Composites via Laser-Induced Exothermic Reactions. Crystals 2021, 11, 535. https://doi.org/10.3390/ cryst11050535

Academic Editors: Zhan Sun,

Zhenwen Yang, Chun Li, Xiaoqing Si and Wei Guo

Received: 20 April 2021

Accepted: 10 May 2021

Published: 12 May 2021

Publisher's Note: MDPI stays neutral with regard to jurisdictional claims in published maps and institutional affiliations.

Copyright: (c) 2021 by the authors. Licensee MDPI, Basel, Switzerland. This article is an open access article distributed under the terms and conditions of the Creative Commons Attribution (CC BY) license (https:// creativecommons.org/licenses/by/ $4.0 /)$.

\begin{abstract}
In this paper, the $\mathrm{SiCp} / \mathrm{Al}$ composites were bonded via laser-induced exothermic reactions of a Ni-Al-Zr interlayer. The Ni-Al-Zr interlayer was designed based on its exothermic property and chemical compatibility with the $\mathrm{SiCp} / \mathrm{Al}$ composites. The influences of the interlayer composition and bonding pressure on the joint microstructure and shear strength were investigated. Results indicated that high exothermic reactions occurred in the $\mathrm{Ni}-\mathrm{Al}-\mathrm{Zr}$ interlayer and realized the reliable bonding with the $\mathrm{SiCp} / \mathrm{Al}$ composites. The interlayer products were the eutectic structure of $\mathrm{NiAl}+\mathrm{Ni}_{2} \mathrm{AlZr}+\mathrm{Ni}_{3} \mathrm{Al}_{5} \mathrm{Zr}_{2} . \mathrm{NiAl}_{3}$ and $\mathrm{Ni}_{2} \mathrm{Al}_{3}$ reaction layers were formed at the bonding interfaces. The interlayer composition and the bonding pressure determined the morphology and distribution of the voids and the reaction layers, thus controlling the joint shear strength. When the $\mathrm{SiCp} / \mathrm{Al}$ composites were bonded using the interlayer with the $\mathrm{Zr}$ content of $15 \mathrm{wt} . \%$ under the bonding pressure of $3 \mathrm{MPa}$, the joint shear strength reached the maximum of $24 \mathrm{MPa}$.
\end{abstract}

Keywords: $\mathrm{SiCp} / \mathrm{Al}$ composites; bonding; laser-induced exothermic reactions; microstructure; mechanical property

\section{Introduction}

Particle-reinforced aluminum matrix composites, such as SiCp/Al composites [1], $\mathrm{Si}_{3} \mathrm{~N}_{4} / \mathrm{Al}$ composites [2], $\mathrm{SiO}_{2} / \mathrm{Al}$ composites [3], $\mathrm{Al}_{2} \mathrm{O}_{3} / \mathrm{Al}$ composites [4], $\mathrm{B}_{4} \mathrm{C} / \mathrm{Al}$ composites [5], and $\mathrm{TiC} / \mathrm{Al}$ composites [6], process excellent electrical and chemical properties, as well as the comprehensive mechanical performances, and have been important structural materials in aerospace, electronics, and automobile industries. Among them, the $\mathrm{SiCp} / \mathrm{Al}$ composites are particularly attracting attention and are usually used to manufacture components with complex structures in practical applications $[7,8]$. However, the poor processibility of the $\mathrm{SiCp} / \mathrm{Al}$ composites have greatly limited their potential applications. The deformation processing will damage the interfacial bonding between the reinforced $\mathrm{SiC}$ particles and the aluminum matrix, thus causing the degeneration of mechanical performances [9]. Due to the $\mathrm{SiC}$ particles with high hardness, machining is also not suitable for the $\mathrm{SiCp} / \mathrm{Al}$ composites [10]. One solution for this issue is that the component with complex structure can be manufactured through bonding modular $\mathrm{SiCp} / \mathrm{Al}$ composite pieces together. From the above viewpoint, developing a technique for reliable bonding $\mathrm{SiCp} / \mathrm{Al}$ composites can further broaden their applications and is of great importance.

Since there are great differences in the chemical and physical properties between the reinforcements and matrix, it is extremely difficult to realize the reliable bonding of $\mathrm{SiCp} / \mathrm{Al}$ composites [11]. It mainly has three difficulties. First, at high temperature, harmful interfacial reactions will occur between the $\mathrm{SiC}$ particles and aluminum matrix, forming a large quantity of brittle $\mathrm{Al}_{4} \mathrm{C}_{3}$ compounds and resulting in the degeneration of mechanical properties. Long et al. [12] investigated the laser welding of SiCp/Al composites. They found that the high temperature during the laser welding led to the evaporation of the aluminum matrix and the excess interfacial reactions, forming large numbers of pores 
and brittle $\mathrm{Al}_{4} \mathrm{C}_{3}$. Adding appropriate $\mathrm{Zr}$ could partly inhibit the generation of large-size brittle phase $\mathrm{Al}_{4} \mathrm{C}_{3}$ in the joint. Second, at low temperature, the SiC particles can hardly react with surrounding materials and the bonding at the interface is very weak. Third, the alumina film on the surface of aluminum matrix also blocks the atomic diffusion at the bonding interface. To achieve a sound joint, during the welding, the interfacial reactions between the reinforcements and matrix should be inhibited to prevent the degradation of materials properties. At the same time, the metallurgical reactions between the $\mathrm{SiC}$ particles and surrounding materials must be enhanced to form a reliable bonding at the interface. To meet the above requirements, the chemical reactions in the bonding couple must be controlled precisely. Unfortunately, although great efforts have been done on the bonding of SiCp/Al composites, these problems have not been solved fundamentally.

Compared with conventional welding techniques, such as fusion welding [13], brazing [14,15], diffusion bonding [16], etc., the exothermic bonding has some inherent advantages on the bonding of $\mathrm{SiCp} / \mathrm{Al}$ composites. It utilizes the exothermic reactions in the interlayer as the heat source to enhance the atomic activities and promote the metallurgical reactions at the bonding interface [17]. It can quickly $\left(10^{5}-10^{6} \mathrm{~K} / \mathrm{s}\right)$ heat the narrow area at the bonding interface to a high temperature (about $2000 \mathrm{~K}$ ), and the adjacent part of substrates remains a low temperature $[18,19]$. The transient high temperature could not only significantly increase the chemical activity of $\mathrm{SiC}$ particles at the bonding interface and enhance the metallurgical reactions with the filler metals, but also avoid the harmful thermal damage on the substrates. Swiston et al. [20] bonded the bulk metallic glass with the assistance of the exothermic reactions in the reactive multilayer foils. They found that during the bonding, the rapid heating and cooling made crystallization of metallic glasses unlikely. The thermal damage on the metallic glasses was voided successfully. Lin et al. [21] bonded carbon-carbon composites using the $\mathrm{Ti} / \mathrm{Ni}-\mathrm{Al} / \mathrm{Ti}$ interlayer. They found that the exothermic reactions in the $\mathrm{Ni}-\mathrm{Al}$ interlayer enhanced the metallurgical reactions and formed the NiAlx and $\operatorname{TiC}_{\mathrm{y}}\left(\mathrm{O}_{\mathrm{z}}\right)$ phases at the bonding interface. In our previous study [22], the $\mathrm{C}_{\mathrm{f}} / \mathrm{Al}$ composites were bonded to the TiAl alloys using the exothermic bonding technique. A defect-free joint was achieved successfully. Although many efforts have been done on this bonding method, the exothermic bonding of $\mathrm{SiCp} / \mathrm{Al}$ composites has been seldom reported.

As a fundamental research, this work is to explore the feasibility of bonding $\mathrm{SiCp} / \mathrm{Al}$ composites via laser-induced exothermic reactions. A Ni-Al-Zr interlayer was designed and used as the bonding interlayer. The exothermic characteristics of the interlayer were analyzed. The typical joint microstructure was characterized. The influences of the bonding parameters on the microstructural evolution and mechanical property of the joint were investigated systematically.

\section{Experimental Procedures}

The $\mathrm{SiCp} / \mathrm{Al}$ composites applied in this study were fabricated using the squeeze casting method. The volume fraction of $\mathrm{SiC}$ particles was $50 \%$ and the aluminum matrix was the 6063 aluminum alloy. The microstructure of the $\mathrm{SiCp} / \mathrm{Al}$ composites was given in Figure 1. Prior to the bonding, the $\mathrm{SiCp} / \mathrm{Al}$ composites were cut into small pieces with the sizes of $12 \mathrm{~mm} \times 6 \mathrm{~mm} \times 2 \mathrm{~mm}$ and $5 \mathrm{~mm} \times 5 \mathrm{~mm} \times 4 \mathrm{~mm}$, respectively. Then, all the bonding surfaces were polished by the diamond abrasive discs to 600\#, and cleared in acetone for $10 \mathrm{~min}$ with the assistance of ultrasonic to remove the impurities.

The raw materials to prepare the powder interlayer were the commercial $\mathrm{Ni}(99.5 \%$, $28 \mu \mathrm{m}), \mathrm{Al}(99.5 \%, 28 \mu \mathrm{m})$, and $\mathrm{Zr}(99.5 \%, 28 \mu \mathrm{m})$ powders purchased from Beijing Xingrongyuan Technology Co., Let. The weighted powders were put in an agate jar and milled with alumina balls for $60 \mathrm{~min}$. Ten (10) $\mathrm{mL}$ Hexane was added in the agate jar as the process controlling agent and to prevent the oxidation of the powders. The rotational speed was set as $300 \mathrm{rpm}$ and the mass ratio of the grinding media to the material was 10:1. Then, $0.5 \mathrm{~g}$ milled powders were cold-pressured to a cylindrical compact ( $\Phi 10 \mathrm{~mm})$. The bonding process was conducted in the argon atmosphere. The joining schematic diagram 
is represented in Figure 2. During the bonding, the exothermic interlayer was applied between the SiCp/Al substrates. A laser beam (YAG-W100E, P = $200 \mathrm{~W}$, Han's Laser Technology Industry Group Co., Ltd, Shenzhen, China) heated the interlayer and ignited the interlayer. Then, the combustion flame propagated to the other side and finished the bonding process.

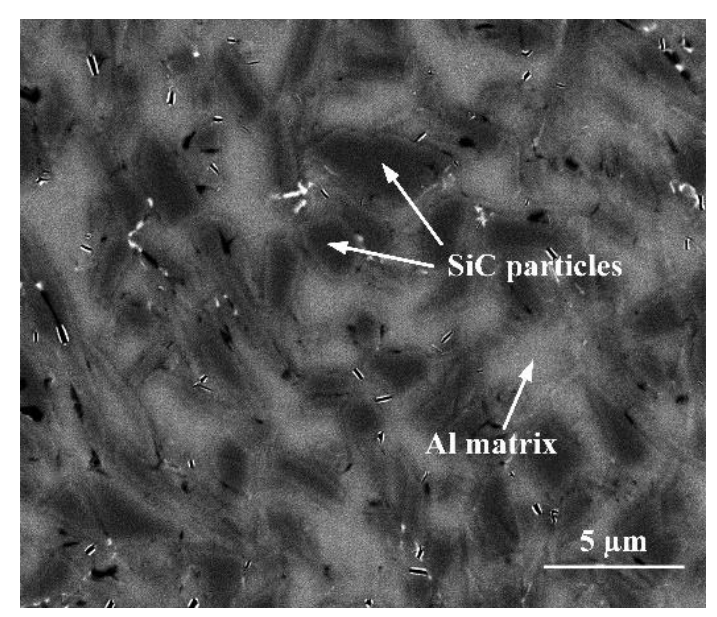

Figure 1. Microstructure of the $\mathrm{SiCp} / \mathrm{Al}$ composites.

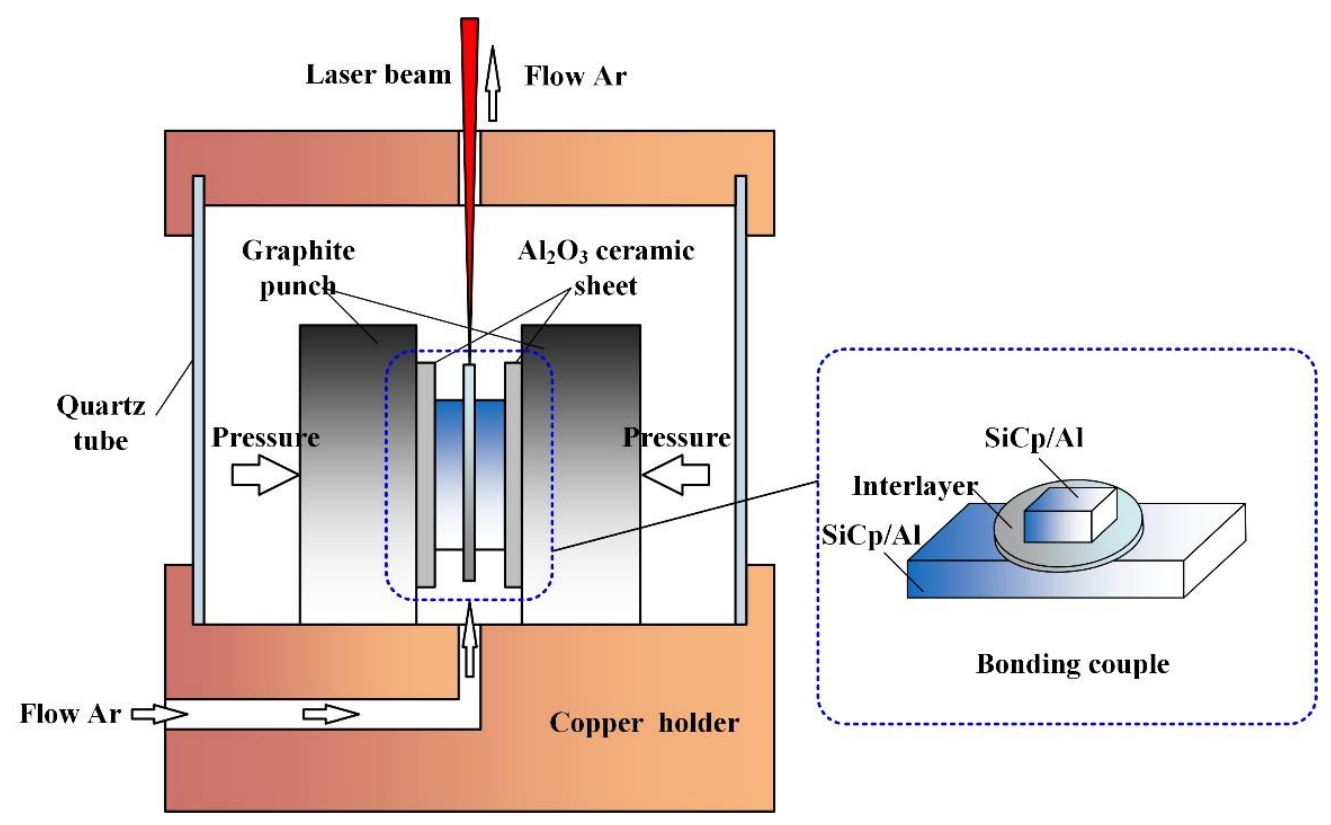

Figure 2. Schematic diagram of the bonding process.

The exothermic performance of the interlayer, the joint interfacial microstructure, and interlayer products were characterized by the differential scanning calorimetry (DSC, NETZSCH STA449C, Erich NETZSCH GmbH \& Co. Holding KG, Selb, Germany), scanning electron microscopy (SEM, FEI Nova400, FEI Company, Hillsboro, OR, USA) equipped with the energy-dispersive spectrometer (EDS, FEI Company, Hillsboro, OR, USA), and X-ray diffraction (XRD, D8 ADVANCE, Bruker Company, Karlsruhe, Germany). The joint shear strength was tested at room temperature using the universal test machine (Instron-1186, Instron Corporation, Canton, $\mathrm{OH}, \mathrm{USA}$ ) with a shear rate of $0.5 \mathrm{~mm} \cdot \mathrm{min}^{-1}$. The schematic diagram of the shear test is shown in Figure 3. 


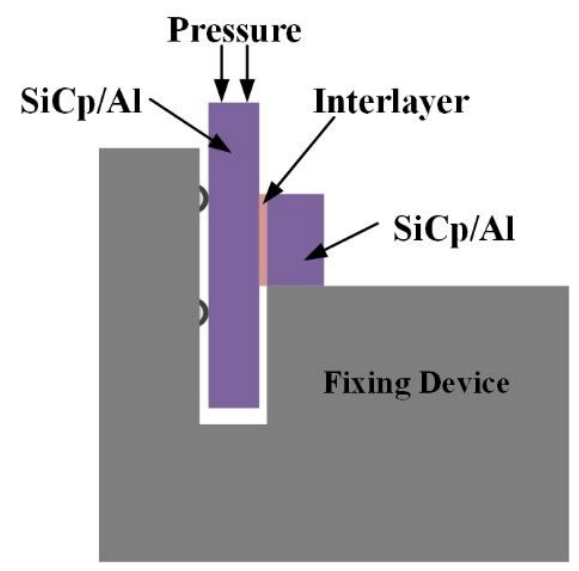

Figure 3. Schematic diagram of the shear test.

\section{Results and Discussion}

\subsection{Design of the Exothermic Interlayer}

Unlike the conventional welding methods, the exothermic bonding depends on the exothermic reactions in the interlayer to supply the required heat. At the same time, the reaction products of the interlayer remains in the bonding couple as a part of the joint. Therefore, the bonding quality is determined by the exothermic characteristics of the bonding interlayer and the properties of the interlayer products. To realize the reliable bonding of the $\mathrm{SiCp} / \mathrm{Al}$ composites, there are two important problems needed to be solved. First, during the bonding process, a reliable metallurgical bonding should be formed between the composites and the filler metals. Second, the harmful interfacial reactions between the reinforcements and matrix should be prevented. Thus, on one hand, it needs a high temperature at the bonding interface to enhance the metallurgical reactions between the $\mathrm{SiC}$ particles and the surrounding materials. On the other hand, the high-temperature region should be localized around the bonding interface and should be as smaller as possible. Meanwhile, the high temperature residence time should also be very short to avoid the excess interfacial reactions in the $\mathrm{SiCp} / \mathrm{Al}$ substrates. In consequence, it requires that the interlayer should have a high exothermicity and a rapid heat releasing characteristic.

There are three kinds of exothermic systems, which were the (i) mixed active metal and nonmetal with a small atomic diameter (Ti-B [23], Ti-C [24], Ti-Al-C [25], Ti-Al-B [26]), (ii) thermites ( $\mathrm{Al}-\mathrm{CuO}$ [27], $\mathrm{Al}-\mathrm{Fe}_{2} \mathrm{O}_{3}$ [28]), and (iii) mixed metals ( $\mathrm{Ni}-\mathrm{Al}$ [29], $\mathrm{Ti}-\mathrm{Al}$ [30]), respectively. Among them, the $\mathrm{Ni}-\mathrm{Al}$ exothermic system has a high exothermic property and a stable combustion characteristic [31]. Thus, the Ni-Al exothermic system was chosen as the fundamental exothermic system. According to the $\mathrm{Ni}-\mathrm{Al}$ phase diagram in Figure $4 \mathrm{a}$, several exothermic reactions can occur between $\mathrm{Ni}$ and Al. Different Ni:Al ratios lead to different exothermic reactions and release different quantity of heat, forming different intermetallic compounds, such as $\mathrm{NiAl}_{3}, \mathrm{Ni}_{2} \mathrm{Al}_{3}, \mathrm{NiAl}, \mathrm{Ni}_{5} \mathrm{Al}_{3}$, and $\mathrm{Ni}_{3} \mathrm{Al}$. To design the exothermic interlayer with the highest exothermicity, the adiabatic temperatures $\left(\mathrm{T}_{\mathrm{ad}}\right)$ of the $\mathrm{Ni}-\mathrm{Al}$ systems with different $\mathrm{Ni}$ :Al ratios were calculated using the following equation.

$$
\Delta \mathrm{H}(298)+\int_{298}^{T_{a d}(298)} \sum n_{j} C_{P}\left(P_{j}\right) d T+\sum_{298 \sim T_{a d}(298)} n_{j} L\left(P_{j}\right)=0
$$

where, $P_{j}$ and $n_{j}$ respectively refer to the products and their stoichiometric coefficients. $C_{P}\left(P_{j}\right)$ and $L\left(P_{j}\right)$ are the heat capacity and phase transformation enthalpy (if a phase change occurs) of the products, respectively. 
(a)

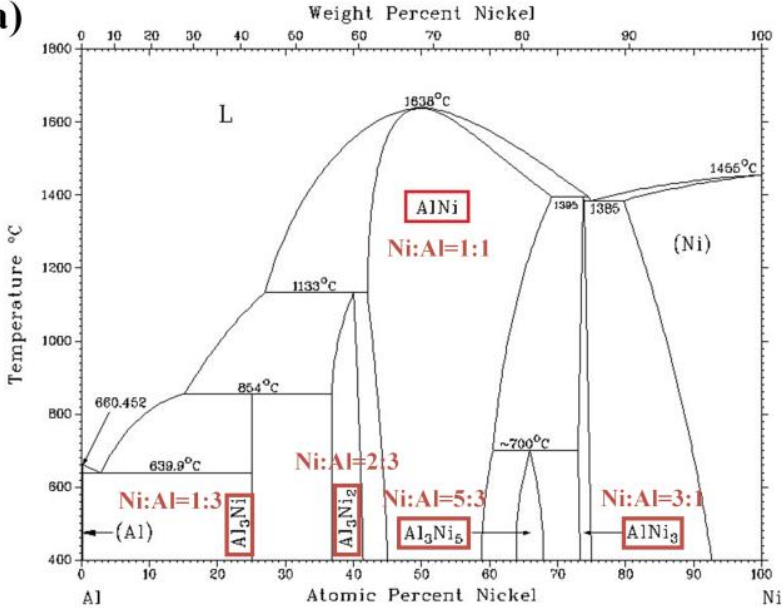

(b) Al-Ni-Zr

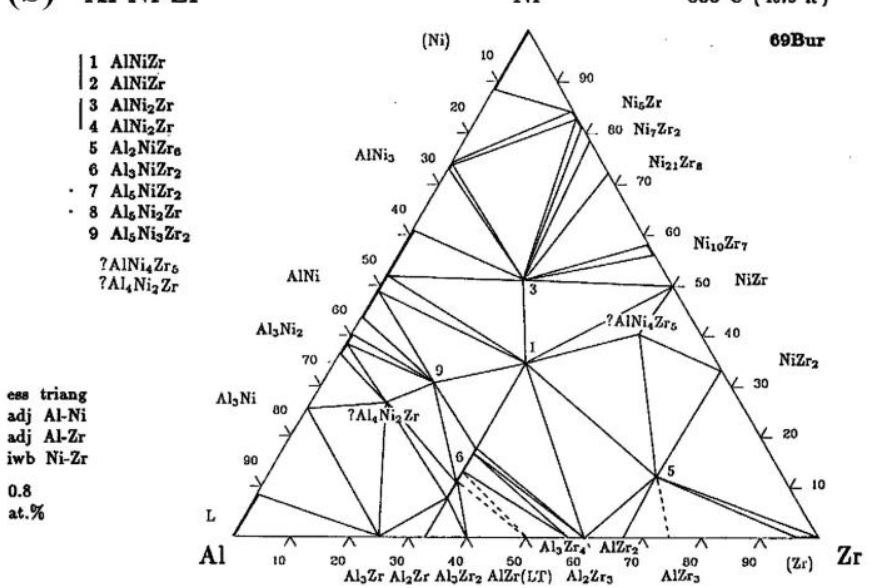

Figure 4. (a) $\mathrm{Ni}-\mathrm{Al}$ phase diagram; (b) Ni-Al-Zr ternary phase diagram.

The calculation results suggest that the equimolar $\mathrm{Ni}-\mathrm{Al}$ system has the highest $\mathrm{T}_{\mathrm{ad}}$ (1912 K). During the exothermic bonding, the combustion stability is also very important. Merzhanov et al. put forward an empirical formula to evaluate the self-sustained reaction [32]. It indicates that when the exothermic reaction has a $\mathrm{T}_{\mathrm{ad}}$ higher than $1800 \mathrm{~K}$, the exothermic reaction can self-sustained. According to the empirical formula, the equimolar $\mathrm{Ni}$-Al system can self-sustained once being ignited.

During the welding of the $\mathrm{SiCp} / \mathrm{Al}$ composites, one problem is the weak bonding between the $\mathrm{SiC}$ particles and filler metals owing to the high chemical inertness of the $\mathrm{SiC}$ reinforcements. To increase the bonding quality, the chemical affinity of the SiC reinforcements and the interlayer products should be promoted. In the brazing of $\mathrm{SiC}$ ceramics, the active filler metals (containing $\mathrm{Ti}$ or $\mathrm{Zr}$ ) were usually used. It indicated that the $\mathrm{Zr}$ element could react with the $\mathrm{SiC}$ ceramics and form the $\mathrm{ZrC}$ and $\mathrm{Zr}_{2} \mathrm{Si}$ reaction layers. By means of the reaction layers between the active elements and the $\mathrm{SiC}$ ceramics, a reliable bonding could be ensured. Thus, in this study, the $\mathrm{Zr}$ element was added into the $\mathrm{Ni}-\mathrm{Al}$ system, forming the $\mathrm{Ni}-\mathrm{Al}-\mathrm{Zr}$ interlayer. There are two reasons to the addition of the $\mathrm{Zr}$ element. First, the $\mathrm{Zr}$ element is the active element and the carbide-forming element. It can easily react with the $\mathrm{SiC}$ particles and form a reliable metallurgical bonding. Second, according to the Ni-Al-Zr ternary phase diagram (Figure $4 \mathrm{~b}$ ), the $\mathrm{Ni}-\mathrm{Al}-\mathrm{Zr}$ system can form a eutectic product of $\mathrm{NiAl}+\mathrm{Ni}-\mathrm{Al}-\mathrm{Zr}$. The formation of the eutectic products can lower the solidification temperature and prolong the existence time of the liquid phase. Thus, under the action of the bonding pressure, the interlayer products can be densified much more easily, which can largely decrease the formation of the voids in the joint.

To evaluate the exothermic property of the interlayer, the DSC test was conducted on the $\mathrm{Ni}-\mathrm{Al}$ and $\mathrm{Ni}-\mathrm{Al}-\mathrm{Zr}$ interlayer (Figure 5). For the Ni-Al interlayer, there were two sharp exothermic peaks, which were located at the heating temperature of $840 \mathrm{~K}$ and $916 \mathrm{~K}$, respectively. The main exothermic peak was at the heating temperature of $840 \mathrm{~K}$. After adding a small amount of $\mathrm{Zr}$ element, the position of exothermic peaks changed slightly and shifted to $762 \mathrm{~K}$ and $904 \mathrm{~K}$, respectively. The height of the exothermic peaks decreased slightly. This is mainly caused by the addition of $\mathrm{Zr}$ acting as a diluent and absorbing some reaction heat. Meanwhile, after the addition of $\mathrm{Zr}$ in the $\mathrm{Ni}-\mathrm{Al}$ interlayer, the position of the main exothermic peak decreased by $78 \mathrm{~K}$, which meant that the exothermic reactions in the interlayer could be ignited more easily. The additive $\mathrm{Zr}$ is necessary since it can largely enhance the metallurgical bonding and increase the bonding quality. If the $\mathrm{Zr}$ content is in an appropriate range, the $\mathrm{Ni}-\mathrm{Al}-\mathrm{Zr}$ interlayer still can maintain a high exothermicity and can provide sufficient heat for the bonding. According to above calculation method and the previous study [17], when the $\mathrm{Zr}$ content ranges in $0 \mathrm{wt} . \% \sim 36.08 \mathrm{wt} . \%$, the $\mathrm{T}_{\mathrm{ad}}$ of the $\mathrm{Ni}-\mathrm{Al}-\mathrm{Zr}$ system was still maintained at a high temperature $(1912 \mathrm{~K})$ and the high exothermicity of the $\mathrm{Ni}-\mathrm{Al}-\mathrm{Zr}$ interlayer could be ensured. 


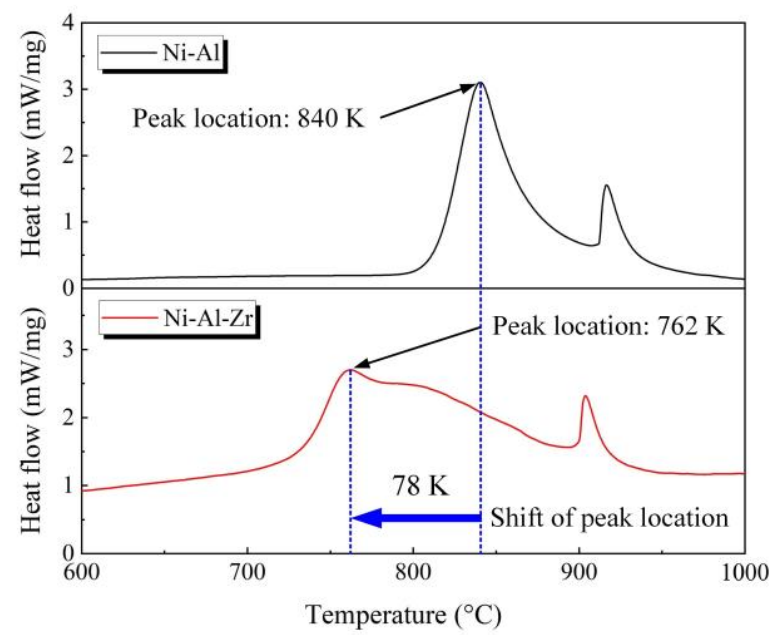

Figure 5. DSC curves of the interlayers.

\subsection{Joint Microstructure}

Figure 6 shows the microstructure of the $\mathrm{SiCp} / \mathrm{Al}$ joint bonded using a $\mathrm{Ni}-\mathrm{Al}-\mathrm{Zr}$ interlayer under a pressure of $3 \mathrm{MPa}$. It could be seen from the overall morphology in Figure $6 \mathrm{a}$ that the interlayer reacted completely and formed a good bonding with the substrates. In the center of the joint, the interlayer products were quite dense. Near the bonding interface, there were some pores and some residual Al. This phenomenon was mainly owing to the particularity of the exothermic bonding. During the bonding, the exothermic reactions occurred in the interlayer and released a great amount of heat. At the center of the interlayer, the interlayer products were maintained at a high temperature and were in a solid-liquid state. Under the bonding pressure, they could be easily densified and the pores were largely eliminated. However, in the regions near the bonding interfaces, the $\mathrm{SiCp} / \mathrm{Al}$ substrates were maintained at the room temperature and absorbed some reaction heat from the interlayer. So, the interlayer products cooled rapidly and could hardly be fully densified, forming the voids in the region near the bonding interface.
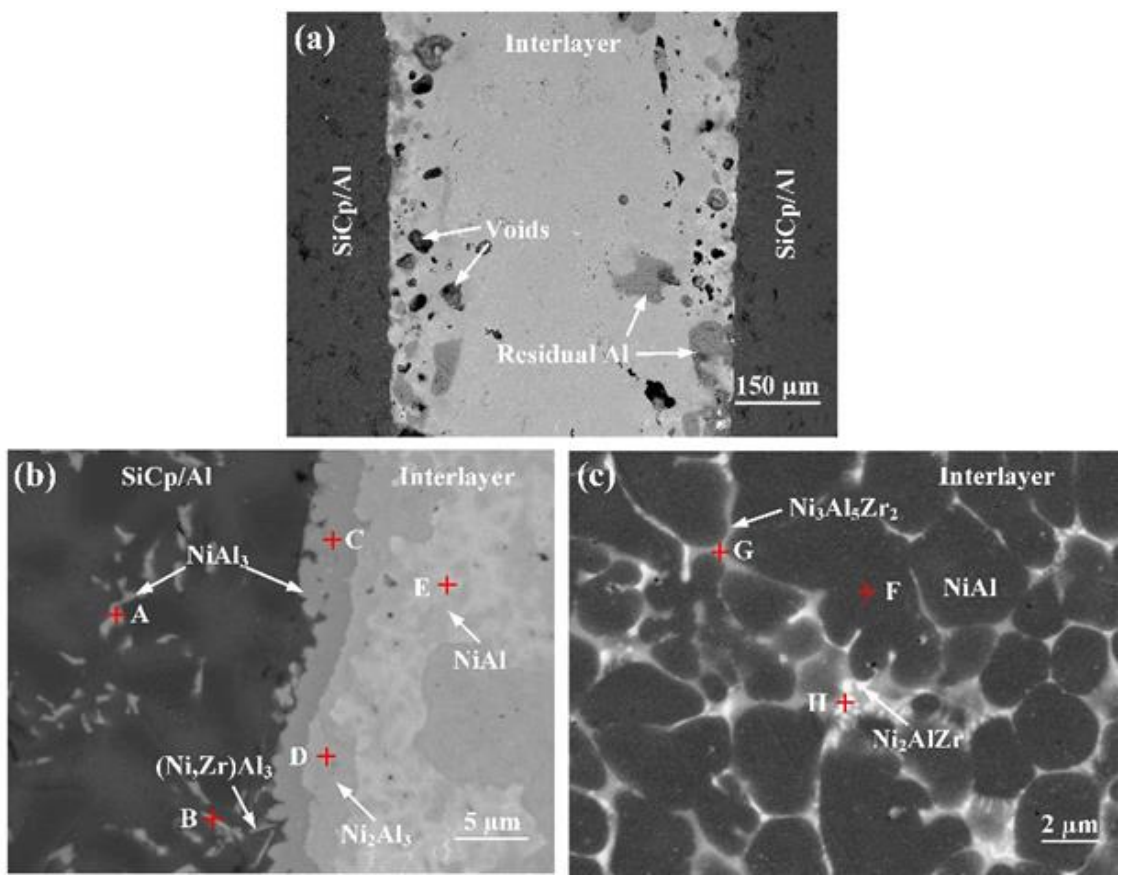

Figure 6. Typical microstructure of the $\mathrm{SiCp} / \mathrm{Al}$ joint bonded with a $\mathrm{Ni}-\mathrm{Al}-\mathrm{Zr}$ interlayer (Zr $15 \mathrm{wt}$ \%, $3 \mathrm{MPa}$ ). (a) The overall joint; (b) the bonding interface; (c) the interlayer products. 
To analyze the characteristics of the joint in detail, the morphologies at the bonding interface and the interlayer products were enlarged in Figure $6 \mathrm{~b}, \mathrm{c}$. It could be seen from Figure $6 \mathrm{~b}$ that at the bonding interface, the interlayer products bonded well with the $\mathrm{SiCp} / \mathrm{Al}$ composites. No cracks and voids can be observed at the bonding interface. In the $\mathrm{SiCp} / \mathrm{Al}$ composites near the bonding interface, some dark gray block phase (point $\mathrm{A}$ ) and white needle-like phase (point B) were formed. Two continuous reaction layers, which were the dark gray layer (point $C$ ) and the gray layer (point $D$ ), were formed at the bonding interface. Near the reaction layers, some off-white phases (point E) were also observed. In Figure $6 c$, the interlayer products presented a eutectic feature. It consisted of large dark block phase (point $\mathrm{F}$ ), gray reticular phase (point $\mathrm{G}$ ), and white small block phase (point $\mathrm{H}$ ). To determine the phase composition of the joint, the EDS analysis was conducted on the above zones and the results were given in Table 1. The dark gray phases (point A and C), gray reaction layer (point $\mathrm{D}$ ), and off-white phase (point $\mathrm{E}$ ) consisted of $\mathrm{Ni}$ and $\mathrm{Al}$ elements. The ratios of Ni:Al were about 1:3, 2:3 and 1:1, respectively. According to the Ni-Al phase diagram and previous studies $[17,22]$, they were supposed to be the $\mathrm{NiAl}_{3}, \mathrm{Ni}_{2} \mathrm{Al}_{3}$, and $\mathrm{NiAl}$, respectively. The white need-like phase (point $\mathrm{B}$ ) consisted of $\mathrm{Ni}, \mathrm{Al}$, and $\mathrm{Zr}$ elements and was confirmed as the $(\mathrm{Ni}, \mathrm{Zr}) \mathrm{Al}_{3}$ phase. The interlayer products were a mixture of three phases. According to the phase diagram and previous studies [33,34], the dark phase (point F) was confirmed to be the NiAl phase. The gray reticular phase (point G) and white small block phase (point $\mathrm{H}$ ) were supposed to be the $\mathrm{Ni}_{3} \mathrm{Al}_{5} \mathrm{Zr}_{2}$ and $\mathrm{Ni}_{2} \mathrm{AlZr}$, respectively. The formation of $\mathrm{Ni}_{3} \mathrm{Al}_{5} \mathrm{Zr}_{2}$ and $\mathrm{Ni}_{2} \mathrm{AlZr}$ was mainly caused by the $\mathrm{Zr}$ atoms replacing the places of $\mathrm{Ni}$ or $\mathrm{Al}$ atoms in the $\mathrm{NiAl}$ space lattice. To further confirm the phase composition of the interlayer products, the XRD test was carried out. The peak refinement was conducted with the assistance of the MDI Jade software. According to the study by Chérif et al. [35] and the peak refinement results in Figure 7, the interlayer products were confirmed as a mixture of $\mathrm{NiAl}+\mathrm{Ni}_{3} \mathrm{Al}_{5} \mathrm{Zr}_{2}+\mathrm{Ni}_{2} \mathrm{AlZr}$, which proved the above analysis.

Table 1. EDS results on zones in Figure 6 (at.\%).

\begin{tabular}{|c|c|c|c|c|}
\hline Zone & $\mathrm{Ni}$ & Al & $\mathrm{Zr}$ & Possible Phase \\
\hline A & 26.63 & 73.37 & - & $\mathrm{NiAl}_{3}$ \\
\hline B & 6.03 & 84.95 & 9.02 & $(\mathrm{Ni}, \mathrm{Zr}) \mathrm{Al}_{3}$ \\
\hline $\mathrm{C}$ & 28.07 & 71.67 & 0.26 & $\mathrm{NiAl}_{3}$ \\
\hline $\mathrm{D}$ & 42.73 & 57.08 & 0.19 & $\mathrm{Ni}_{2} \mathrm{Al}_{3}$ \\
\hline $\mathrm{E}$ & 60.33 & 39.67 & - & NiAl \\
\hline $\mathrm{F}$ & 50.45 & 47.51 & 2.04 & $\mathrm{NiAl}$ \\
\hline G & 37.93 & 42.17 & 19.9 & $\mathrm{Ni}_{3} \mathrm{Al}_{5} \mathrm{Zr}_{2}$ \\
\hline $\mathrm{H}$ & 53.03 & 25.39 & 21.59 & $\mathrm{Ni}_{2} \mathrm{AlZr}$ \\
\hline
\end{tabular}

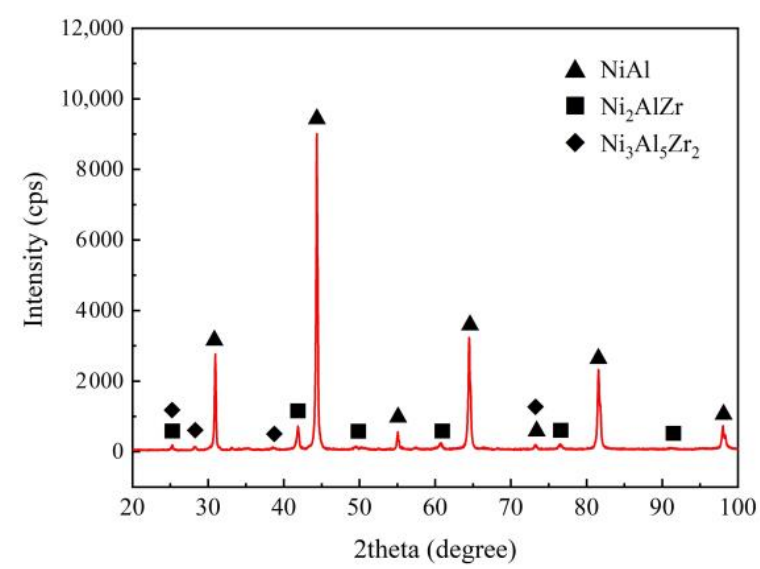

Figure 7. XRD results of the interlayer products. 


\subsection{Influence of the Interlayer Chemical Composition on the Joint Microstructure}

With the increase of $\mathrm{Zr}$ content in the interlayer, the joint morphology underwent a dramatic change, as shown in Figure 8. These changes were mainly displayed in two aspects. First, with the increase of the $\mathrm{Zr}$ content, the density of the joint had a significant improvement. The amount and the size of the voids in the joint decreased obviously. Second, with the increase of the $\mathrm{Zr}$ content, the residual white Ni particles gradually increased. When the $\mathrm{Zr}$ content was $20 \mathrm{wt} . \%$, there were large numbers of the residual $\mathrm{Ni}$ particles around the bonding interfaces and some large voids were also observed at the bonding interfaces.
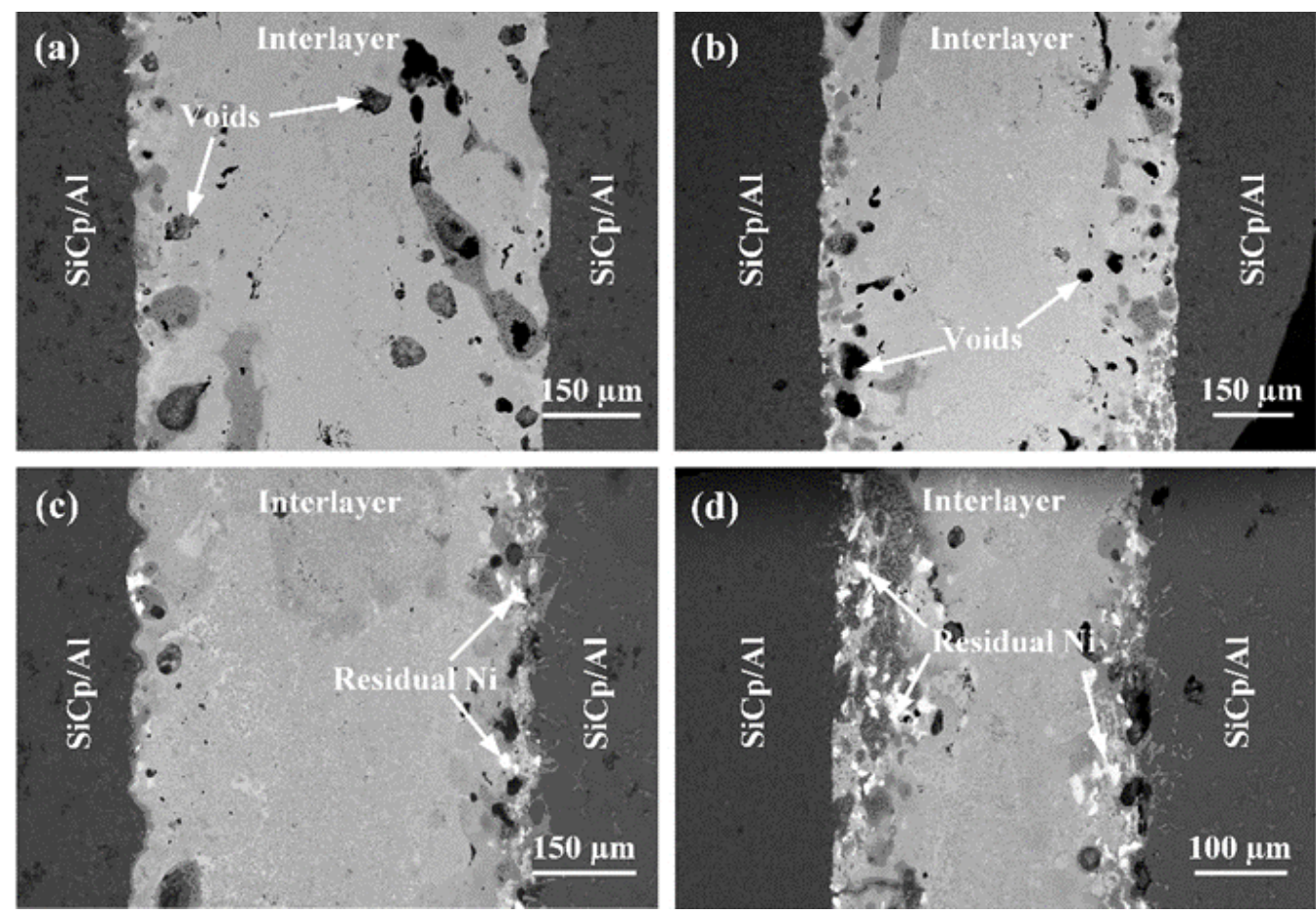

Figure 8. Microstructures of the joints bonded with different interlayers. (a) Zr 5 wt.\%; (b) 8 wt.\%; (c) 15 wt. \%; (d) 20 wt.\%.

To analyze the microstructure of the joints in detail, the regions of the interlayer products and the bonding interfaces were enlarged in Figures 9 and 10, respectively. It could be seen that the interlayer products with different $\mathrm{Zr}$ contents all presented a eutectic morphology of mixed dark $\mathrm{NiAl}$ phase and white $\mathrm{Ni}-\mathrm{Al}-\mathrm{Zr} \mathrm{IMC}$, as shown in Figure 9. When the $\mathrm{Zr}$ content was $5 \mathrm{wt} . \%$, the $\mathrm{Ni}-\mathrm{Al}-\mathrm{Zr} \mathrm{IMC}$ was less and separated by the dark block NiAl phase. With the increase of the $\mathrm{Zr}$ content, its volume fraction increased gradually. The Ni-Al-Zr IMC became continuous gradually and the grain of the $\mathrm{NiAl}$ phase decreased obviously. Compared with the NiAl phase, the ternary Ni-Al-Zr compounds had a much higher hardness and brittleness [36]. Thus, with the increase of the $\mathrm{Zr}$ content, the high-volume fraction of the $\mathrm{Ni}-\mathrm{Al}-\mathrm{Zr}$ IMC increased the brittleness of the interlayer products. On the other hand, the higher volume fraction of the $\mathrm{Ni}-\mathrm{Al}-\mathrm{Zr}$ IMC also meant the increase of the eutectic liquid in the interlayer products. During the exothermic bonding process, the higher volume fraction of the eutectic liquid promoted the densification process and was conducive to eliminating the voids in the joints. Thus, the amount and the sizes of the voids in the joint gradually decreased. 

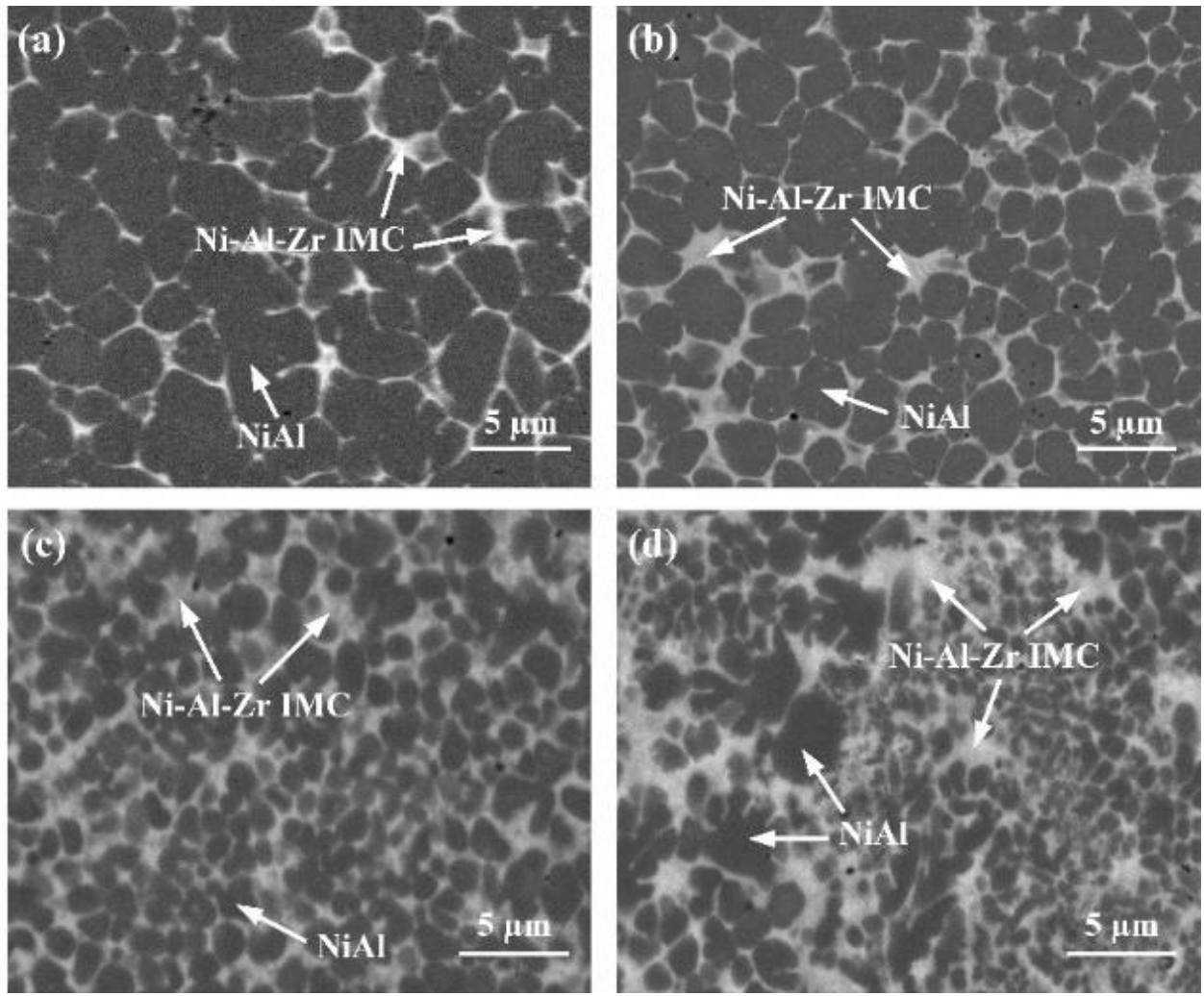

Figure 9. Microstructures of the different interlayer products. (a) $\mathrm{Zr} 5$ wt.\%; (b) 8 wt.\%; (c) 15 wt.\%; (d) $20 \mathrm{wt} . \%$.
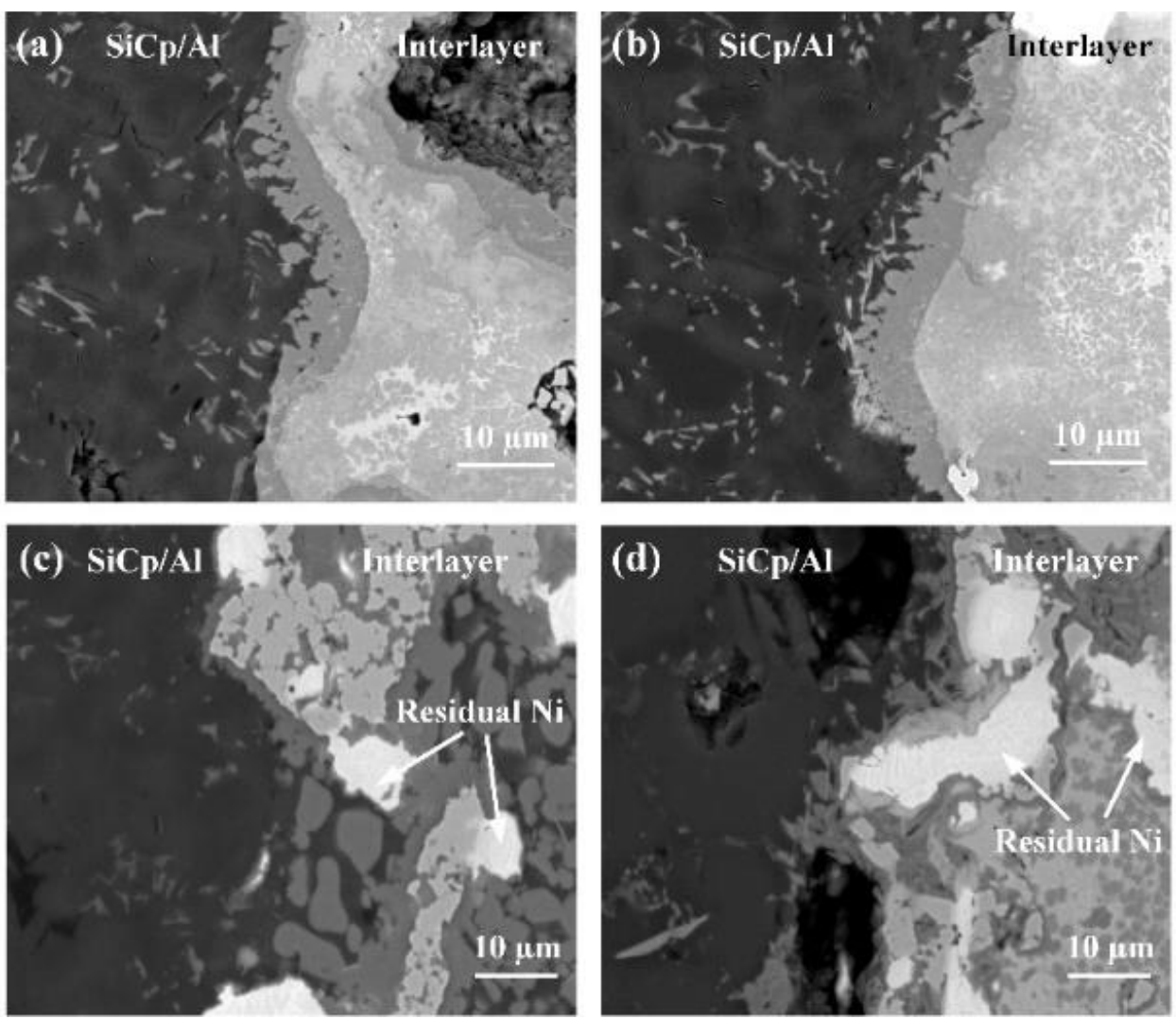

Figure 10. Interfacial bonding characteristics of the joints bonded with different interlayers. (a) Zr 5 wt.\%; (b) 8 wt.\%; (c) 15 wt.\%; (d) 20 wt.\%. 
The interfacial microstructures of the different bonding interfaces with different $\mathrm{Zr}$ contents were demonstrated in Figure 10. With the increase of the Zr content, the interfacial microstructures at the bonding interfaces mainly changed in two ways. On one hand, the $\mathrm{NiAl}_{3}$ and $\mathrm{Ni}_{2} \mathrm{Al}_{3}$ reaction layers at the interfaces became discontinuous gradually. On the other hand, the amount and the size of the residual Ni particles increased gradually at the bonding interfaces. These changes were mainly due to the different exothermicities of the interlayers with different $\mathrm{Zr}$ contents. The analysis in Section 3.1 indicated that the exothermic reactions between the $\mathrm{Ni}$ and $\mathrm{Al}$ could release a large quantity of heat and provided the required energy for the bonding process. During the bonding, the additive $\mathrm{Zr}$ absorbed some reaction heat and acted as the coolant. Thus, with the increase of the $\mathrm{Zr}$ content, the exothermicity of the interlayer had a slightly decrease. The decrease of the exothermicity shorted the high-temperature residence time of the bonding interface and reduced the atomic activity at the bonding interface, thus affecting the interfacial reaction. The reaction layers became thinner and continuous gradually. Meanwhile, since the interlayer exothermicity decreased with the increase of the $\mathrm{Zr}$ content and the $\mathrm{SiCp} / \mathrm{Al}$ composites absorbed some heat, the cooling rate at the bonding interface increased significantly. It affected the exothermic reactions in this region. The reactions in this region were incomplete and some residual Ni particles were observed. With the increase of the $\mathrm{Zr}$ content, the residual Ni particles became more and more plentiful. Zr element is a carbide-forming element. Qi et al. [37] and Zhou et al. [38] brazed SiC ceramics with filler metals containing $\mathrm{Zr}$ element. They suggested the $\mathrm{Zr}$ element promoted the metallurgical reactions between the $\mathrm{SiC}$ ceramic and the filler metals. In this study, the higher $\mathrm{Zr}$ content in the interlayer also enhanced the bonding quality between the $\mathrm{SiCp} / \mathrm{Al}$ composites and the interlayer. As the $\mathrm{Zr}$ content increased, the voids and the unconnected areas gradually disappeared. When the $\mathrm{Zr}$ content was $15 \mathrm{wt}$ \% , the SiCp/Al composites had a reliable bonding with the interlayer and no defects were observed at the bonding interface. However, with the further increase of the $\mathrm{Zr}$ content, the voids appeared again due to the low exothermicity of the interlayer.

\subsection{Influence of the Bonding Pressure on the Joint Microstructure}

The microstructures of the $\mathrm{SiCp} / \mathrm{Al}$ joints bonded at different bonding pressures were shown in Figure 11. Under different bonding pressures, the density of the joints changed significantly. The reaction products were the eutectic structure of $\mathrm{NiAl}+\mathrm{Ni}-\mathrm{Al}-\mathrm{Zr}$ IMC, as shown in Figure 6. During the bonding process, the interlayer products were in the solid-liquid state. Under the action of the bonding pressure, the interlayer products were squeezed by the adjacent substrates, and the original pores in the interlayer could be largely eliminated. The higher the bonding pressure was, the denser the interlayer products were. When the bonding pressure was low (1.5 $\mathrm{MPa})$, a large number of the voids were observed in the joint. With the increase of the bonding pressure, the amount and size of the voids decreased significantly. When the bonding pressure reached $3 \mathrm{MPa}$, large voids disappeared in the joint. There were only some small voids distributed in the region adjacent to the bonding interface. The density and bonding quality of the joint had a dramatic improvement. When the bonding pressure further increased to $4 \mathrm{MPa}$, the small voids around the bonding interfaces almost disappeared. The joint density was quite high. However, since the interlayer products were a mixture of brittle $\mathrm{NiAl}$ and $\mathrm{Ni}-\mathrm{Al}-\mathrm{Zr}$ IMC, under high bonding pressure, a fracture occurred in the interlayer products and propagated to the $\mathrm{SiC} / \mathrm{Al}$ composites, as shown in Figure 11d.

\subsection{Joint Shear Strength}

The shear strength was used to evaluate the joint mechanical property. With the increase of the $\mathrm{Zr}$ content in the interlayer, the joint shear strength first increased and reached the highest value (24 MPa) when the $\mathrm{Zr}$ content was $15 \mathrm{wt} . \%$, then it decreased to $15 \mathrm{MPa}$, as shown in Figure 12. The joint shear strength depended on the joint microstructure [39]. As analyzed in Section 3.3, the Zr content influenced the joint microstructure in three ways, 
which were (i) the joint density, (ii) the residual Ni particles, and (iii) the reaction layers at the bonding interfaces, respectively. When the Zr content was $5 \mathrm{wt} \%$, the interlayer products were mainly the NiAl phase. The low-volume fraction of the Ni-Al-Zr IMC led to less eutectic liquid during the bonding process. Thus, the original pores in the interlayer were unable to be eliminated effectively. The large number of the voids in the joint greatly affected the mechanical property of the joint. With the increase of the Zr content, the amount and size of the voids in the joint decreased significantly. When the Zr content was $8 \mathrm{wt} . \%$, the voids were small and mainly distributed around the bonding interfaces. The joint shear strength slightly increased to $16 \mathrm{MPa}$. When the $\mathrm{Zr}$ content reached $15 \mathrm{wt}$ \%, the voids in the joint further decreased. However, the high $\mathrm{Zr}$ content slightly reduced the exothermicity of the interlayer. Since the adjacent $\mathrm{SiCp} / \mathrm{Al}$ substrates absorbed some reaction heat from the interlayer, the reactions in the region near the bonding interfaces were incomplete. Some residual Ni particles were observed around the bonding interfaces. The decrease of the interlayer exothermicity also affected the interfacial reactions at the bonding interfaces. The reaction layers became thinner and uncontinuous gradually. It should be noticed that there was a competitive relationship between the joint density and the reaction layers. With the increase of the Zr content, the joint density gradually increased, which was beneficial to the joint shear strength. Meanwhile, the reaction layers became thinner and uncontinuous gradually, which had unfavorable effects for the bonding quality. The joint mechanical performance was a combined result of these two aspects. When the Zr content was $15 \mathrm{wt} . \%$, these two aspects were in a balance. Thus, the joint shear strength reached the highest value $(24 \mathrm{MPa})$. With the further increase of the $\mathrm{Zr}$ content, the joint density did not continue to increase. The high fraction of $\mathrm{Ni}-\mathrm{Al}-\mathrm{Zr}$ IMC greatly increased the brittleness of the interlayer products. The large amount of the residual Ni particles and the thin reaction layers greatly affected the bonding quality. Thus, the joint shear strength decreased to $15 \mathrm{MPa}$ when the $\mathrm{Zr}$ content was $20 \mathrm{wt} . \%$.
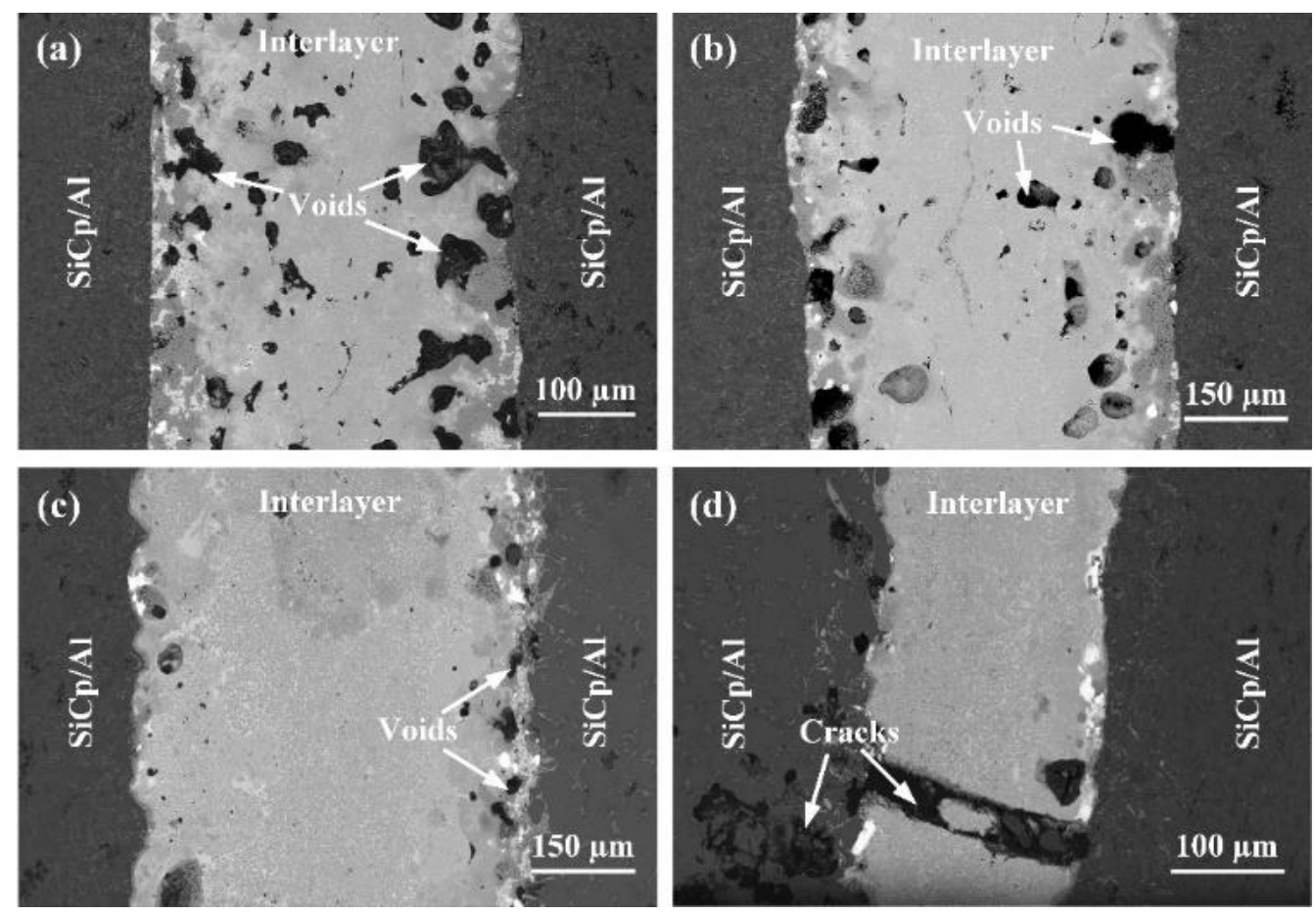

Figure 11. Microstructures of the joints bonded under different pressures. (a) $1.5 \mathrm{MPa}$; (b) $2 \mathrm{MPa}$; (c) $3 \mathrm{MPa}$; (d) $4 \mathrm{MPa}$. 

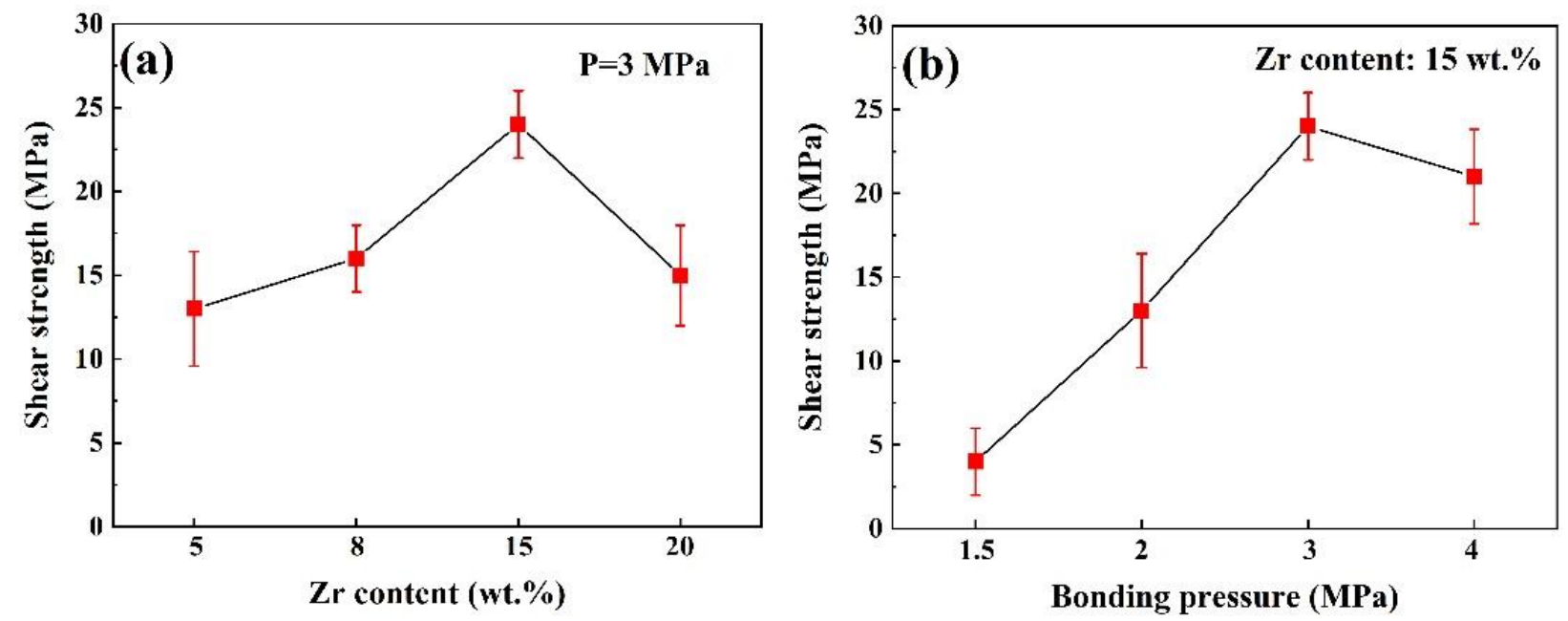

Figure 12. Influence of the (a) interlayer composition and (b) bonding pressure on the joint shear strength.

The influence of the bonding pressure on the joint shear strength was similar to that of $\mathrm{Zr}$ content, as shown in Figure 12. The bonding pressure mainly influenced the joint density. When the bonding pressure was $1.5 \mathrm{MPa}$, the interlayer products only had small extrusion deformation. The original pores in the interlayer were largely kept in the joint. The large amount of the voids decreased the joint's ability to withstand loads. The joint shear strength was as low as $4 \mathrm{MPa}$. With the increase of the bonding pressure, the interlayer products suffered a larger extrusion deformation, which effectively reduced the amount and size of the voids. In consequence, the joint shear strength had an obvious increase. When the bonding pressure was $3 \mathrm{MPa}$, there were only some small voids distributed around the bonding interfaces. The joint shear strength reached the maximum of $24 \mathrm{MPa}$. When the bonding pressure further increased to $4 \mathrm{MPa}$, the high pressure led to the fracture of the brittle interlayer products. Continuous cracks were formed in the joint. It significantly affected the joint mechanical performance. The joint shear strength decreased to $21 \mathrm{MPa}$.

\section{Conclusions}

(1) The equimolar Ni-Al system was chosen as the fundamental exothermic system due to its high exothermic property. The active $\mathrm{Zr}$ element was added to promote the metallurgical reactions between the $\mathrm{SiC}$ particles and the interlayer. $\mathrm{NiAl}_{3}, \mathrm{Ni}_{2} \mathrm{Al}_{3}$ reaction layers were formed at the bonding interfaces and ensured the reliable bonding of the $\mathrm{SiCp} / \mathrm{Al}$ composites.

(2) The additive $\mathrm{Zr}$ transformed the interlayer products from the $\mathrm{NiAl}$ to the eutectic organization of $\mathrm{NiAl}+\mathrm{Ni}_{2} \mathrm{AlZr}+\mathrm{Ni}_{3} \mathrm{Al}_{5} \mathrm{Zr}$. Higher $\mathrm{Zr}$ content increased the joint density, but slightly decreased the interlayer exothermicity and led to the thin reaction layers. Higher bonding pressure increased the extrusion deformation of the interlayer products and effectively eliminated the original pores in the interlayer products.

(3) With the increase of the $\mathrm{Zr}$ content and the bonding pressure, the joint shear strength first increased and then decreased. When the $\mathrm{Zr}$ content was $15 \mathrm{wt} . \%$ and the bonding pressure was $3 \mathrm{MPa}$, the joint shear strength reached the maximum of $24 \mathrm{MPa}$.

Author Contributions: Conceptualization, G.F. and Y.W. (Yifeng Wang); methodology, G.F.; software, Y.W. (Yan Wei); validation, B.H. and Y.W. (Yan Wei); formal analysis, G.F. and Y.W. (Yan Wei); investigation, G.F. and Y.W. (Yifeng Wang); resources, B.H.; data curation, Y.W. (Yan Wei); writingoriginal draft preparation, G.F.; writing-review and editing, G.F. and Y.W. (Yan Wei); visualization, D.D.; supervision, Y.W. (Yifeng Wang) and D.D.; project administration, G.F.; funding acquisition, G.F. All authors have read and agreed to the published version of the manuscript.

Funding: This work was funded by the National Natural Science Foundation of China (No. 51905055), the Natural Science Foundation of Chongqing (No. cstc2020jcyj-msxmX0115), and the Fundamental Research Funds for the Central Universities Project (No. 2020CDJ-LHZZ-086). 
Institutional Review Board Statement: Not applicable.

Informed Consent Statement: Not applicable.

Data Availability Statement: Not applicable.

Conflicts of Interest: The authors declare no conflict of interest and non-financial interest requiring disclosure in this article.

\section{References}

1. Chen, R.F.; Zhao, Y.H.; Shen, Z.X.; Dai, L.G.; Zhang, X.L.; Zhu, R. Study on the Joint Strength of SiCp/ Al Metal Matrix Composite by Magnetron Sputtering Method. Mater. Sci. Forum 2009, 628-629, 569-574. [CrossRef]

2. Venkatachalam, A.; Anurag, P.V.S.; Sadanand, T.D.; Nachimuthu, R. Optimization of the milling parameters for an $\mathrm{Al}_{/} \mathrm{Si}_{3} \mathrm{~N}_{4}$ functionally graded composite using grey relational analysis. Mater. Test 2018, 60, 215-221. [CrossRef]

3. Zhang, W.; Xiao, D.; Ding, D. A first-principles investigation of interfacial properties and electronic structure of $\mathrm{SiO}_{2} / \mathrm{Al}_{\text {interface }}$ Comput. Mater. Sci. 2021, 188. [CrossRef]

4. Wang, X.; Chen, Z.; Ma, T.; Zhu, D.; Dong, D.; Yang, X.; Liu, L.; Wang, G. Evolution of primary and eutectic Si phase and mechanical properties of $\mathrm{Al}_{2} \mathrm{O}_{3} / \mathrm{Al}-20 \mathrm{Si}$ composites under high pressure. Crystals 2021, 11, 364. [CrossRef]

5. Guo, H.; Zhang, Z.; Zhang, Y.; Cui, Y.; Sun, L.; Chen, D. Improving the mechanical properties of $\mathrm{B}_{4} \mathrm{C} / \mathrm{Al}$ composites by solid-state interfacial reaction. J. Alloy. Compd. 2020, 829. [CrossRef]

6. Duygulu, O. High-resolution transmission electron microscopy investigation of in situ TiC/Al composites. Met. Mater. 2018, 56, 265-275. [CrossRef]

7. Qiao, Q.; Su, Y.; Cao, H.; Zhang, D.; Ouyang, Q. Effect of post-weld heat treatment on double-sided friction stir welded joint of $120 \mathrm{~mm}$ ultra-thick SiCp/Al composite plates. Mater. Charact. 2020, 169, 110668. [CrossRef]

8. Adebisi, A.A.; Maleque, M.A.; Ali, M.Y.; Bello, K.A. Effect of variable particle size reinforcement on mechanical and wear properties of 6061Al-SiCp composite. Compos. Interface 2016, 23, 533-547. [CrossRef]

9. Xiang, D.; Zhang, Z.; Wu, B.; Feng, H.; Shi, Z.; Zhao, B. Effect of Ultrasonic Vibration Tensile on the Mechanical Properties of High-Volume Fraction SiCp/Al Composite. Int. J. Precis. Eng. Man. 2020, 21, 2051-2066. [CrossRef]

10. Huang, S.T.; Zhou, L.; Chen, J.; Xu, L.F. Drilling of SiCp/Al Metal Matrix Composites with Polycrystalline Diamond (PCD) Tools. Mater. Manuf. Process. 2012, 27, 1090-1094. [CrossRef]

11. Kwok, Y. Effects of pulse-impact on the welding of SiCP/Al-6061 aluminium matrix composites. Mater. Sci. Technol. 2017, 33, 2298-2304. [CrossRef]

12. Long, J.; Zhang, L.J.; Zhang, L.L.; Wang, X.; Zhang, G.F.; Zhang, J.X.; Na, S.J. Effects of minor Zr addition on the microstructure and mechanical properties of laser welded joint of Al/SiCp metal-matrix composite. J. Manuf. Process. 2020, 49, 373-384. [CrossRef]

13. Xi-He, W.; Ji-Tai, N.; Shao-Kang, G.; Le-Jun, W.; Dong-Feng, C. Investigation on TIG welding of SiCp-reinforced aluminum-matrix composite using mixed shielding gas and Al-Si filler. Mater. Sci. Eng. A 2009, 499, 106-110. [CrossRef]

14. Wang, P.; Gao, Z.; Niu, J. Micro-nano filler metal foil on vacuum brazing of SiCp/Al composites. Appl. Phys. A 2016, 122. [CrossRef]

15. Chen, H.; Nai, X.; Zhao, S.; Lu, D.; Shen, Z.; Li, W.; Cao, J. Improvement for interfacial microstructure and mechanical properties of $\mathrm{Ti}_{3} \mathrm{SiC}_{2} / \mathrm{Cu}$ joint brazed by Ag-Cu-Ti filler with copper mesh. Crystals 2021, 11, 401. [CrossRef]

16. Gao, Z.; Yang, H.; Feng, J.; Ji, F.; Niu, J.; Brnic, J. Flux-Free Diffusion Joining of SiCp/6063 Al Matrix Composites Using Liquid Gallium with Nano-Copper Particles in Atmosphere Environment. Nanomaterials 2020, 10, 437. [CrossRef]

17. Feng, G.; Li, Z.; Zhou, Z.; Wang, Y. Joining of Cf/Al composites and TiAl intermetallics by laser-induced self-propagating high-temperature synthesis using the Ni-Al-Zr interlayer. Mater. Des. 2016, 110, 130-137. [CrossRef]

18. Trenkle, J.C.; Koerner, L.J.; Tate, M.W.; Gruner, S.M.; Weihs, T.P.; Hufnagel, T.C. Phase transformations during rapid heating of $\mathrm{Al} / \mathrm{Ni}$ multilayer foils. Appl. Phys. Lett. 2008, 93. [CrossRef]

19. Pascal, C.; Marin-Ayral, R.M.; Tedenac, J.C. Joining of nickel monoaluminide to a superalloy substrate by high pressure selfpropagating high-temperature synthesis. J. Alloy. Compd. 2002, 337, 221-225. [CrossRef]

20. Swiston, A.J.; Hufnagel, T.C.; Weihs, T.P. Joining bulk metallic glass using reactive multilayer foils. Scripta Mater. 2003, 48, 1575-1580. [CrossRef]

21. Lin, Y.C.; Nepapushev, A.A.; Mcginn, P.J.; Rogachev, A.S.; Mukasyan, A.S. Combustion joinining of carbon/carbon composites by a reactive mixture of titanium and mechanically activated nickel/aluminum powders. Ceram. Int. 2013, 39, 7499-7505. [CrossRef]

22. Feng, G.; Li, Z.; Jacob, R.J.; Yang, Y.; Wang, Y.; Zhou, Z.; Sekulic, D.P.; Zachariah, M.R. Laser-induced exothermic bonding of carbon fiber/Al composites and TiAl alloys. Mater. Des. 2017, 126, 197-206. [CrossRef]

23. Royal, T.E.; Namjoshi, S.; Thadhani, N.N. Mechanistic processes influencing shock chemistry in powder mixtures of the Ti-Si, Ti-Al, and Ti-B systems. Met. Mater. Trans. A 1996, 27, 1761-1771. [CrossRef]

24. Manukyan, K.V.; Lin, Y.; Rouvimov, S.; McGinn, P.J.; Mukasyan, A.S. Microstructure-reactivity relationship of Ti plus C reactive nanomaterials. J. Appl. Phys. 2013, 113. [CrossRef]

25. Ligachev, A.E.; Potemkin, G.V.; Lepakova, O.K.; Zhidkov, M.V.; Teresov, A.D.; Golobokov, N.N.; Maksimov, Y.M.; Kolobov, Y.R.; Koval, N.N. Ignition of a Ti-Al-C System by an Electron Beam. Combust. Explo Shock+ 2018, 54, 158-164. [CrossRef] 
26. Epshteyn, A.; Weismiller, M.R.; Huba, Z.J.; Maling, E.L.; Chaimowitz, A.S. Optimization of a High-Energy Ti-Al-B Nanopowder Fuel. Energy Fuels 2017, 31, 1811-1819. [CrossRef]

27. Umbrajkar, S.M.; Schoenitz, M.; Dreizin, E.L. Exothermic reactions in Al-CuO nanocomposites. Thermochim. Acta 2006, 451, 34-43. [CrossRef]

28. Song, J.; Guo, T.; Yao, M.; Chen, J.; Ding, W.; Bei, F.; Mao, Y.; Yu, Z.; Huang, J.; Zhang, X.; et al. A comparative study of thermal kinetics and combustion performance of $\mathrm{Al} / \mathrm{CuO}, \mathrm{Al} / \mathrm{Fe}_{2} \mathrm{O}_{3}$ and $\mathrm{Al} / \mathrm{MnO}_{2}$ nanothermites. Vacuum 2020, 176. [CrossRef]

29. Shteinberg, A.S.; Lin, Y.; Son, S.F.; Mukasyan, A.S. Kinetics of High Temperature Reaction in Ni-Al System: Influence of Mechanical Activation. J. Phys. Chem. A 2010, 114, 6111-6116. [CrossRef] [PubMed]

30. Cao, J.; Feng, J.C.; Li, Z.R. Joining of TiAl intermetallic by self-propagating high-temperature synthesis. J. Mater. Sci. 2006, 41, 4720-4724. [CrossRef]

31. Morris, C.J.; Mary, B.; Zakar, E.; Barron, S.; Fritz, G.; Knio, O.; Weihs, T.P.; Hodgin, R.; Wilkins, P.; May, C. Rapid initiation of reactions in $\mathrm{Al} / \mathrm{Ni}$ multilayers with nanoscale layering. J. Phys. Chem Solids 2010, 71, 84-89. [CrossRef]

32. Naiborodenko, Y.S.; Lavrenchuk, G.V.; Filatov, V.M. Self-propagating high-temperature synthesis of aluminides I. Thermodynamic analysis. Powder Metall. Met. Ceram. 1982, 21, 909-912. [CrossRef]

33. Feng, G.; Li, Z.; Zhou, Z.; Yang, Y.; Sekulic, D.P.; Zachariah, M.R. Microstructure and mechanical properties of C-f/Al-TiAl laser-assisted brazed joint. J. Mater. Process. Technol. 2018, 255, 195-203. [CrossRef]

34. Feng, G.; Li, Z.; Feng, S.; Zhang, W. Microstructure evolution and formation mechanism of laser-ignited SHS joining between $\mathrm{Cf} / \mathrm{Al}$ composites and TiAl alloys with Ni-Al-Ti interlayer. Rare Metals 2017, 36, 746-752. [CrossRef]

35. Chérif, A.; Bachaga, T.; Saurina, J.; Suñol, J.J.; Khitouni, M.; Makhlouf, T. Morphology and structure effect of Ti additive on the solid-state reaction between $\mathrm{Ni}$ and $\mathrm{Al}$ powders during mechanical alloying. Int. J. Adv. Manuf. Technol. 2016, 86, 2937-2943. [CrossRef]

36. Li, Z.; Feng, G.; Wang, S.; Feng, S. High-efficiency Joining of Cf/Al Composites and TiAl Alloys under the Heat Effect of Laser-ignited Self-propagating High-temperature Synthesis. J. Mater. Sci. Technol. 2016, 32, 1111-1116. [CrossRef]

37. Qi, Q.; Zhang, J.; Hu, H.; Lu, C. Benefits of Zr additive element in the Ti-24Ni eutectic filler in vacuum brazing of SiC ceramics. Vacuum 2019, 162, 110-113. [CrossRef]

38. Zhou, B.; Wang, J.; Feng, K.; Cai, Y.; Chen, S. Effect of Brazing Parameters on the Microstructure and Properties of SiC Ceramic Joint with Zr-Cu Filler Metal. Crystals 2020, 10, 93. [CrossRef]

39. Simoes, S.; Sofia Ramos, A.; Viana, F.; Teresa Vieira, M.; Vieira, M.F. TiAl diffusion bonding using Ni/Ti multilayers. Weld. World 2017, 61, 1267-1273. [CrossRef] 